\title{
Is Imprisonment Criminogenic?
}

A Comparative Study of Recidivism Rates Associated with Terms of Imprisonment and Suspended Prison Sentences ${ }^{1}$

\author{
José Cid \\ Criminologia Aplicada a la Penologia \\ Department of Political Science and Public Law \\ Universitat Autònoma de Barcelona \\ e-mail: Josep.Cid@uab.es
}

The final, definitive version of this paper has been published in European Journal of Criminology, 6(6): 459-480, 2009, by SAGE Publications Ltd.

Available at http://dx.doi.org/ 10.1177/1477370809341128 


\begin{abstract}
This article examines the effects of custodial versus non-custodial sentences on recidivism. An 8-year follow-up study was conducted to track and compare rates of recidivism between former prisoners and offenders who had served a suspended prison sentence. Drawing upon a representative sample of 483 offenders sentenced in 1998 by the Criminal Courts of Barcelona, two subpopulations of offenders were selected. The first group consisted of offenders who were sentenced to prison $(n=179)$ while the comparison group was composed of those who were given a suspended prison sentence $(\mathrm{n}=304)$. After controlling for other risk factors predictive of recidivism, logistic regression techniques were used to examine whether the variable "type of sanction" (prison or suspended prison sentence) predicts reconviction rates. The analysis revealed that the offenders given suspended sentences had a lower risk of reconviction than those given custodial sentences. The findings provide evidence that alternatives to custody are more effective than imprisonment in reducing recidivism. Finally, the article discusses how these findings relate to labelling and specific deterrence theories that make contradictory claims regarding the effects of imprisonment on recidivism.
\end{abstract}




\section{INTRODUCTION}

In the debate regarding criminal policies that may reduce recidivism, the starting point should be an evaluation of the effectiveness of different sentencing options that are more likely to achieve this penal aim. Two main theories concerning the effects of imprisonment on rates of recidivism are particularly relevant: specific deterrence and labelling theory. This article provides a test of these two theories drawing upon recidivism statistics. According to specific deterrence, prison sentences are more effective than non-custodial sentences in reducing future criminal behaviour. In contrast, the labelling perspective suggests that non-custodial sentences will produce better results than imprisonment in reducing recidivism. Several studies have examined the effects of imprisonment on recidivism in comparison to alternative or non-custodial sanctions. Given that their results are inconclusive (see below), this research extends the literature by empirically testing both theories and comparing the recidivism of offenders who were sentenced to prison with recidivism among a matched control group of offenders who were given a suspended sentence.

\section{PRISON VERSUS SUSPENDED SENTENCES}

The two sanctions compared in this research are prison and suspended sentences. The Spanish sentencing system is based on a determinate model -between a minimum and a maximum term- for every offence. For most offences, the only available sentence is prison; for some less serious offences, however, the law gives the judge the power to decide between prison and a non-custodial sentence. The sentencing process consists of two stages: in the first, the judge has to decide upon the sentence, choosing between the minimum and the maximum term established by the law. If at this stage the sanction imposed is prison up to two years, a second stage commences in which the judge has to 
come to a decision as to whether this prison sentence may be suspended or replaced by a non-custodial sentence, or whether the offender should be imprisoned.

In this research, I use the term 'prison' or 'imprisonment' to describe a prison sentence that has been executed, since in the second stage the convicted offender has been denied suspension of the prison sentence or its replacement with a non-custodial sentence. During their imprisonment, offenders may benefit from programmes aimed at rehabilitation, in particular resettlement programs based on leave, open prison-with work outside prison - and parole (Cid 2005). However, these programmes are not universal and at least half of the prisoners in the Spanish penitentiary system do not take part in this process of transition from the deprivation of freedom to unconditional release (Cid and Tébar, forthcoming). The prisoners in the sample analyzed in this study belong mostly to the category of prisoners excluded from such rehabilitation programmes.

The term 'suspended sentence' is used to define a prison sentence that is suspended provided that the offender does not commit any other offences in a fixed period of time (usually two years). There are two forms of suspended sentence available to judges: 'suspended sentence' (in which the only requirement of the offender is not to re-offend during the established period) and 'suspended sentence plus probation', in which offenders have the additional obligation of following treatment or an educational program to deal with their criminogenic needs. Given that the suspended sentence plus probation is very rarely used by Spanish judges, almost all the offenders in our research who benefited from the suspended sentence had no other requirement than not to commit a new offence. Only $6 \%$ of the offenders who received suspended sentences were required to follow a rehabilitation programme (consisting in all cases of drugaddiction treatment). 


\section{Theories explaining the relationship between type of penal sanction and recidivism}

According to specific deterrence theory, a custodial sentence will produce less recidivism than alternatives to prison because imprisonment has a "suppression effect" defined as "... a tendency of the first experience of imprisonment to reduce the rate of offending" (Wilson 1983: 130). One possible explanation for the "suppression effect" could be that offenders sentenced to prison perceive imprisonment as more aversive than less serious penalties (Windzio 2006). According to this interpretation, specific deterrence theory may be linked to rational choice theory in that, when considering the balance of costs and benefits prior to committing an offence, offenders with a previous experience of imprisonment will raise the cost of every crime that could be attributed to a prison sentence (Windzio 2006).

In contrast to specific deterrence theory, labelling theory claims that a prison sentence will generate more recidivism than non-custodial sanctions due to its criminogenic effect. The theory predicts that offenders sentenced to prison will recidivate to a greater degree than offenders who received a non-custodial sanction. The criminogenic effect of prison is based on two different processes: first, some prisoners may accept the self-image of a deviant given by the institution (Lemert 1972). Second, prison has an indirect effect on recidivism since ex-convicts experience greater difficulties in obtaining employment and maintaining social and personal relations than people sentenced to non-custodial sanctions (Sampson and Laub 1993) ${ }^{2}$

\section{Methods used to compare rates of recidivism}

Research into the deterrent or labelling effects of imprisonment usually compares rates of recidivism for offenders sentenced to prison with those for offenders sentenced to non-custodial penalties. According to the "Scientific Methods Scale adapted for 
Reconviction Studies" developed by Harper and Chitty (2005: 7) on the basis of the Maryland Scientific Methods Scale (Farrington et al. 2002; Sherman et al. 1997) recidivism studies can be classified using 5 levels, level 1 being the lowest standard of research and level 5 the highest.

Level 1 studies employ a simple comparison between rates of recidivism for offenders sentenced to prison with those for offenders sentenced to non-custodial penalties. This method does not allow any generalized claim about the greater effectiveness of non-custodial sanctions to reduce recidivism because it is reasonable to expect that offenders at a higher risk of reconviction would have been sentenced to prison and that it is therefore their previous higher risk of committing an offence rather than the type of sentence itself that is the main reason for their higher recidivism rate (Lloyd, May and Hough 1994).

Level 2 studies are based on a pre-test risk assessment of a group of offenders sentenced to different penalties (prison and non-custodial sentences) giving an expected reconviction rate that is then compared with the actual reconviction rates of offenders. If rate of recidivism is significantly different to predicted risk, it could be accepted that the type of penalty has an effect on recidivism (Raynor 2007). The main problem with this research design is the limitation of the risk-assessment instrument to capture all risk factors considered by judges in deciding on type of punishment.

Level 3 studies employ a quasi-experimental method with an unmatched comparison group. This is probably the most frequently used category to date. These studies draw on samples of offenders sentenced to different penalties and analyse the capacity of the different risk factors to predict recidivism. When the type of sanction is itself one of these risk factors, it could be concluded that it has an effect on recidivism. The main problem with this research method lies with the selection of the risk factors 
considered in the research. If, for example, judges use non-custodial sanctions more often for socially integrated offenders this could lead to the spurious finding that prison is a variable that predicts recidivism (Raynor 2007). ${ }^{4}$

Level 4 studies consist of quasi-experimental research designs in which the rate of recidivism of the group of offenders sentenced to prison is compared with a wellmatched group of offenders sentenced to a non-custodial penalty. The control group should be as similar as possible to the experimental group in order to restrict the effects of external influences. The control group comes from matching, rather than randomization. When matching is achieved, any possible differences in the rates of recidivism can be attributed to the type of penalty imposed. Finally, the highest standard of research (level 5) consists of using a true experiment in which treatments (prison or a suspended sentence) are randomly assigned to experimental units (offenders). This technique, despite being the most methodologically rigorous, is seldom used for obvious ethical reasons. Table 1 summarises the outcomes of recent research.

\section{[TABLE 1]}

\section{Research Hypothesis}

As can be seen in Table 1, so far, the results of previous research into the effects of custodial and non-custodial sanctions on re-offence are inconsistent and it is possible that the theories in dispute—-specific deterrence and labelling — both have an influence on the explanation of the relationship between the type of penalty and subsequent recidivism (Blumstein 2004). Although the empirical evidence is inconclusive, there is more support for the labelling perspective (see Table 1). It therefore appears reasonable to assume this theoretical perspective as a framework to develop the research hypothesis of the present study. This hypothesis will be confirmed if, after comparing a custodial 
with a non-custodial sentence, offenders who have received a term of imprisonment are more likely to recidivate than those who received an alternative sanction.

\section{METHODOLOGY}

\section{Data}

Data were obtained from 1,418 offenders sentenced in 1998 by the Criminal Courts of Barcelona for an offence for which the maximum penalty is no more than three years imprisonment. These data were used in previous research conducted by Cid-Larrauri et al. (2002) to explore the use of discretion by Spanish penal judges (see Table 2).

\section{[TABLE 2]}

This study examines the impact of sanctions on the criminal careers of 241 offenders sentenced to prison, and of 304 offenders who received a suspended sentence. Sixty-two individuals from the prison group were excluded from the analysis for two reasons: 1) For still being in prison during the follow-up period, therefore without having the possibility of re-offending; 2) For having been released from prison less than one year before the end of the follow-up period, therefore complicating detection of any possible new offence. The final sample, whose characteristics are described in Table 3, is composed of 483 offenders: 179 who served unsuspended prison sentences and 304 who served suspended sentences. The average sentence length for the 179 offenders in the prison group was 9.5 months. The 304 offenders from the suspended-sentence group were given a suspended sentence for an average prison term of almost 8 months. The suspension period was for 2 years for most of the individuals.

[TABLE 3]

\section{Dependent variable and follow-up period}

Our principal outcome measure was criminal recidivism. Of the most common methods used in previous studies to operationalise recidivism as a measure of failure - 
subsequent arrests, new convictions and imprisonment—recidivism is measured in this research using a single factor: any new imprisonment. Using re-incarceration as a measure of recidivism has the disadvantage of producing lower rates of recidivism compared to more liberal measures of recidivism (such as arrest or reconviction). However, this is acceptable since the aim of this research is simply to compare such rates between two kinds of penalties. ${ }^{5}$

The criminal activity of our sample of offenders was tracked from the date of sentencing for the suspended-sentence group (1998), or from the date of release for the prison-sentence group, through to 2005 . An offender is considered a recidivist in this study if within the follow-up period he/she is re-admitted to prison regardless of his/her sentence status — pre-trial or sentenced — for committing a new offence. This unusually long follow-up period is justifiable as a way of responding to the slow Spanish judicial system ${ }^{6}$. This might have biased the results in favour of the suspended sentence if new offences committed by this group of offenders were less serious than those committed by the prisoner group, since it would therefore take longer for the offender to be imprisoned.

\section{Independent variables and data analysis}

The present study has taken into account most variables identified by previous research as being related to recidivism, including: age, gender, nationality, type of offence, criminal record, previous imprisonment, substance abuse, financial problems and type of sentence. ${ }^{7}$ First, chi-square techniques were used to test which of the independent variables was statistically associated with recidivism. Second, a logistic regression technique was conducted to determine which combination of variables best predicts 
recidivism and, more specifically, to assess whether "type of sanction" is one of the variables associated with the probability of recidivism.

\section{RESULTS}

\section{Time of recidivism}

The overall rate of recidivism for the 483 offenders followed up for eight years was $36 \%$. Figure 1 displays the general recidivism rate for all offenders. As noted in the chart, rates of recidivism increase more quickly within the two first years and rise more slowly as the follow-up period increases. Although these percentages are consistent with the usual follow-up time of the research, Figure 2 reveals that time to re-offend among offenders granted suspended sentences was longer than for those who received a prison sanction. This justifies the extended follow-up period of this research.

\section{[FIGURE 1]}

\section{[FIGURE 2]}

\section{Risk factors associated with recidivism}

As shown in Table 4, among the factors analyzed, the following variables were significantly related to recidivism: criminal record, previous incarceration, financial problems, drug abuse and type of sanction. Conversely, neither age, sex, type of offence or nationality was significantly related to recidivism.

\section{[TABLE 4]}

\section{Type of sanction and risk of recidivism}

Table 4 reports the percentages of offenders in both groups who re-offended. A chisquare test shows that the two groups were very dissimilar with regard to rates of recidivism: $73.2 \%$ of the prison group versus $13.8 \%$ of the suspended-sentence group. However, since the design of this study is neither experimental nor quasi-experimental with an equivalent control group, it is hard to compare raw recidivism rates associated 
with the sanctions. Moreover, since the two groups may be dissimilar with respect to other risk factors (i.e., type of offence, criminal history), it cannot be concluded that a prison sentence per se increases the probabilities of recidivism. In fact, as revealed by Table 5, the proportion of offenders that meet the risk criteria is significantly higher in the prison group than in the suspended-sentence group.

\section{[TABLE 5]}

In order to ascertain whether the type of sanction given to the offender affects recidivism, in the next phase of the analysis we examined recidivism and the influence of risk factors. To that end, we developed a measure of risk to be applied to both groups. Our measure included the following factors traditionally used in predicting future criminal behaviour, namely previous imprisonment, type of sanction, criminal records, drug abuse, and financial problems.

Using logistical regression, recidivism was regressed for our group of explanatory variables. The results in Table 6 show the logit model that provides the best fit. This model includes the risk variables termed "previous imprisonment" and "prison sentence", and the protection variable termed "no previous offences". All three variables are correlated significantly with recidivism. Although as shown by the values of $\mathrm{B}$ and $\operatorname{Exp}(\mathrm{B})$ the "previous imprisonment" variable is the explanatory variable that most increases risk of recidivism, "prison sentence" (as opposed to a suspended sentence), also increases the probability of recidivism (see Appendix 1 for a more detailed explanation of the logistic regression analysis).

\section{[TABLE 6]}

A second series of logistic-regression recidivism equations is used to assess how well the type of sanction predicts recidivism. In this phase of the analysis, the offenders are classified into three risk categories: low (offenders with no previous convictions and 
without previous imprisonment); medium (offenders with previous convictions but without previous imprisonment) and high (offenders with previous convictions and with previous imprisonment). After examining recidivism and the influence of risk level, the results (as presented in Figure 3), indicate that for all three levels of risk, offenders who received a prison sentence are more likely to recidivate during the eight-year follow up period. In other words, the probability of recidivism increases in either the low, medium or high-risk category of offenders when the sanction granted is prison rather than a suspended sentence (see Appendix 2 for more detail).

\section{[FIGURE 3]}

\section{DISCUSSION AND CONCLUSION}

The findings of this research provide empirical support for labelling theory: our findings suggest that prison sanctions do not reduce recidivism more effectively than suspended sentences. On the contrary, the risk of recidivism increases when the offender is imprisoned. Although specific deterrence theory should be interpreted as the "suppression effect" of the first experience of incarceration, our research is not compatible with this theory since the increase in the risk of recidivism following incarceration applies both to offenders incarcerated for the first time as well as offenders with previous incarcerations.

The results of this research are therefore compatible with labelling theory, according to which prison is likely to lead to higher rates of recidivism (compared to a suspended sentence). It is possible that some of the offenders sent to prison might experience a process of self-definition as offenders. In addition, offenders released from prison may encounter barriers to establishing social links. These factors- which do not apply to offenders who received a suspended sentence - may explain differences in the risk of recidivism. Moreover, also consistent with labelling theory is the fact that 
variations in this risk following incarceration or a suspended sentence are especially pronounced for offenders who have undergone their first imprisonment. This is due to secondary deviation, in which the effects of the first prison sentence seem more relevant than further imprisonments.

Two methodological caveats should be made regarding this research. First, given that the research design is not experimental (equivalent treatment and control groups), it is possible that the higher rates of recidivism for the prison group were not a consequence of their imprisonment, but rather an effect of risk factors taken into account by judges, but not included in the present research. There are two aspects to this objection. On the one hand, it has to be considered that the sample used in this research was previously used in a study by Cid and Larrauri et al. (2002) to identify variables used by judges in deciding between prison and non-custodial sentences. All those factors in that previous research that were statistically significant in the use of discretion by judges have also been considered in this research ${ }^{8}$. On the other hand, it is possible that the previous research ignored certain risk factors considered by judges. In particular, the prediction of risk made by judges was not taken into account by the 2002 research because there is no formal assessment of risk in the Spanish sentencing process. In our research, we assumed that the prediction of risk made by judges should have been based on the factors outlined in the written procedures that were taken into account by the Cid and Larrauri team (2002).

The second criticism is that, given that in $32.4 \%$ of the cases the decision for a prison sentence was mandatory for judges, factors used by the law to make prison mandatory- a prison sentence of more than two years or an extended criminal record may have been risk factors for recidivism not considered by the research. To eliminate this possibility, we examined whether rates of recidivism for offenders sentenced to 
prison for a mandatory reason were significantly higher than those for offenders sentenced to prison by a discretionary decision of the judge. The results were negative in this respect.

The effects of "type of punishment" on further criminal activity have been the object of much theoretical controversy. Specific deterrence theory and labelling theory make contradictory claims about the effects on recidivism following sentencing to prison or on being given a non-custodial sentence. Previous research is inconclusive, although it appears to provide more support for labelling theory. Our research found that offenders sentenced to prison have a higher probability of recidivism than those with a suspended sentence. Although labelling may be considered to have been supported by this research, it should be emphasised that the effects of imprisonment on recidivism may not be due to labelling (or at least not exclusively so), but rather to the breakdown in social factors as a consequence of exclusion from society. Our research is unable to distinguish between this different kind of effect (see note 1).

These findings have two practical consequences. On the one hand, in order to reduce recidivism it seems reasonable to replace prison with non-custodial sentences; this is especially important when the offender has no previous experience of imprisonment. On the other hand, with high-risk offenders it has been found that although the risk of recidivism increases if the penalty is imprisonment, the re-offending rate is also very high when the penalty is a suspended sentence. In order to deal with the criminogenic needs of this latter type of offender, it would be reasonable for judges to add to a suspended sentence the obligation to participate in a rehabilitation programme. 
Appendix 1 Logic regression analysis

Multicolinearity among variables

\begin{tabular}{|c|c|c|c|c|c|c|}
\hline & & $\begin{array}{l}\text { Previous } \\
\text { imprison- } \\
\text { ment }\end{array}$ & $\begin{array}{l}\text { Prison } \\
\text { sentence }\end{array}$ & $\begin{array}{l}\text { Previous } \\
\text { convic- } \\
\text { tions }\end{array}$ & $\begin{array}{l}\text { Drug } \\
\text { addiction }\end{array}$ & $\begin{array}{l}\text { Financial } \\
\text { problems }\end{array}$ \\
\hline \multirow{3}{*}{$\begin{array}{l}\text { Previous } \\
\text { imprison- } \\
\text { ment } \\
\end{array}$} & $\begin{array}{l}\text { Pearson } \\
\text { correlation }\end{array}$ & 1 & .633 & -.623 & .219 & -.379 \\
\hline & Sig. & & .000 & .000 & .000 & .000 \\
\hline & $\mathrm{N}$ & 541 & 541 & 519 & 497 & 522 \\
\hline \multirow[t]{3}{*}{$\begin{array}{l}\text { Prison } \\
\text { sentence }\end{array}$} & $\begin{array}{l}\text { Pearson } \\
\text { correlation }\end{array}$ & .633 & 1 & -.844 & .209 & -.346 \\
\hline & Sig. & .000 & . & .000 & .000 & .000 \\
\hline & $\mathrm{N}$ & 541 & 541 & 519 & 497 & 522 \\
\hline \multirow{3}{*}{$\begin{array}{l}\text { Previous } \\
\text { convictions } \\
\end{array}$} & $\begin{array}{l}\text { Pearson } \\
\text { correlation }\end{array}$ & -.623 & -.844 & 1 & -.210 & .356 \\
\hline & Sig. & .000 & .000 & . & .000 & .000 \\
\hline & $\mathrm{N}$ & 519 & 519 & 519 & 486 & 505 \\
\hline \multirow[t]{3}{*}{$\begin{array}{l}\text { Drug } \\
\text { addiction }\end{array}$} & $\begin{array}{l}\text { Pearson } \\
\text { correlation }\end{array}$ & .219 & .209 & -.210 & 1 & -.092 \\
\hline & Sig. & .000 & .000 & .000 &. & .042 \\
\hline & $\mathrm{N}$ & 497 & 497 & 486 & 497 & 490 \\
\hline \multirow[t]{3}{*}{$\begin{array}{l}\text { Financial } \\
\text { problems }\end{array}$} & $\begin{array}{l}\text { Pearson } \\
\text { correlation }\end{array}$ & -.379 & -.346 & .356 & -.092 & 1 \\
\hline & Sig. & .000 & .000 & .000 & .042 &. \\
\hline & $\mathrm{N}$ & 522 & 522 & 505 & 490 & 522 \\
\hline
\end{tabular}

Summary of cases considered

\begin{tabular}{|l|l|l|l|}
\hline $\begin{array}{l}\text { Cases } \\
\text { considered }\end{array}$ & N & Percentage \\
\hline Cases selected & Included in the analysis & 431 & 79.7 \\
\hline & Missing cases & 110 & 20.3 \\
\hline & Total & 541 & 100.0 \\
\hline $\begin{array}{l}\text { Cases not } \\
\text { selected }\end{array}$ & & 0 & .0 \\
\hline Total & & 541 & 100.0 \\
\hline
\end{tabular}

\begin{tabular}{|c|c|c|}
\hline \multicolumn{2}{|c|}{$\begin{array}{l}\text { Variables included in the } \\
\text { model }\end{array}$} & $\begin{array}{ll}- & \text { PREVIOUS IMPRISONMENT } \\
- & \text { TYPE OF PENALTY (PRISON OR SUSPENDED SENTENCE) } \\
\text { - } & \text { CRIMINAL RECORD } \\
- & \text { DRUG ADDITION } \\
\text { - } & \text { FINANCIAL PROBLEMS }\end{array}$ \\
\hline \multirow{4}{*}{$\begin{array}{l}\text { Method: } \\
\text { Forward } \\
\text { stepwise }\end{array}$} & $\begin{array}{l}\text { Hosmer and } \\
\text { Lemeshow }\end{array}$ & $\begin{array}{l}\text { Value of statistic }: 8.081 \\
\text { Signification: } 0.426\end{array}$ \\
\hline & VIF & $1 /(1-0.400)=1.667$ \\
\hline & $\begin{array}{l}\% \text { of correct } \\
\text { classification }\end{array}$ & $\begin{array}{lr}\text { Non recidivist : } & 87.6 \% \\
\text { Recidivist : } & 75.8 \% \\
\text { Global: } & 83.3 \% \\
\end{array}$ \\
\hline & $\begin{array}{l}\text { Variables in the } \\
\text { equation }\end{array}$ & $\begin{array}{ll}\text { - } & \text { Previous imprisonment } \\
\text { - } & \text { Type of penalty (prison-suspension) } \\
\text { - } & \text { Criminal record }\end{array}$ \\
\hline
\end{tabular}


$\operatorname{Recidivism}($ yes/no $)=\alpha+\beta_{1}$ (Previous imprisonment $)+\beta_{2}$ (Type of penalty $)+\beta_{3}($ criminal record $)$

\begin{tabular}{|l|l|l|l|}
\hline VARIABLE & & $\boldsymbol{\beta}$ & \multirow{3}{*}{ Constant $(\boldsymbol{\alpha})$} \\
\hline \multirow{2}{*}{$\begin{array}{l}\text { Previous } \\
\text { imprisonment }\end{array}$} & Yes & 1.891 & \\
\cline { 2 - 3 } & No & 0.000 & \multirow{3}{*}{ Type of penalty } \\
\cline { 1 - 2 } & Prison & 1.079 & \\
\cline { 2 - 3 } Criminal record & Suspended sentence & 0.000 & \\
& $\begin{array}{l}\text { No previous } \\
\text { convictions }\end{array}$ & -1.068 & \\
\cline { 2 - 3 } & Previous convictions & 0.000 & \\
\hline
\end{tabular}

\begin{tabular}{|l|l|l|l|l|l|l|}
\hline & B & E.T. & Wald & gl & Sig. & $\operatorname{Exp}(\mathrm{B})$ \\
\hline Previous imprisonment & 1.891 & .335 & 31.881 & 1 & .000 & 6.627 \\
\hline Prison sentence & 1.079 & .443 & 5.928 & 1 & .015 & 2.940 \\
\hline No previous convictions & -1.068 & .462 & 5.346 & 1 & .021 & .344 \\
\hline Constant & -1.479 & .483 & 9.368 & 1 & .002 & .228 \\
\hline
\end{tabular}


Appendix 2: Risk of recidivism

\begin{tabular}{|c|c|c|c|c|c|c|c|c|}
\hline \multicolumn{3}{|c|}{ Categories of variables } & \multirow[t]{2}{*}{$\alpha$} & \multicolumn{3}{|l|}{$\beta$} & \multirow[t]{2}{*}{$z$} & \multirow[t]{2}{*}{ Prob. } \\
\hline $\begin{array}{l}\text { Previous } \\
\text { imprison- } \\
\text { ment }\end{array}$ & $\begin{array}{l}\text { Type of } \\
\text { penalty }\end{array}$ & $\begin{array}{l}\text { Criminal } \\
\text { record }\end{array}$ & & $\begin{array}{l}\text { Previous } \\
\text { imprison- } \\
\text { ment }\end{array}$ & $\begin{array}{l}\text { Type of } \\
\text { penalty }\end{array}$ & $\begin{array}{l}\text { Criminal } \\
\text { record }\end{array}$ & & \\
\hline No & $\begin{array}{l}\text { Suspended } \\
\text { sentence }\end{array}$ & $\begin{array}{l}\text { No previous } \\
\text { convictions }\end{array}$ & -1.479 & 0.000 & 0.000 & -1.068 & -2.547 & 0.073 \\
\hline No & $\begin{array}{l}\text { Suspended } \\
\text { sentence }\end{array}$ & $\begin{array}{l}\text { Previous } \\
\text { convictions }\end{array}$ & -1.479 & 0.000 & 0.000 & 0.000 & -1.479 & 0.186 \\
\hline No & Prison & $\begin{array}{l}\text { No Previous } \\
\text { convictions }\end{array}$ & -1.479 & 0.000 & 1.079 & -1.068 & -1.468 & 0.187 \\
\hline Yes & $\begin{array}{l}\text { Suspended } \\
\text { sentence }\end{array}$ & $\begin{array}{l}\text { No Previous } \\
\text { convictions }\end{array}$ & -1.479 & 1.891 & 0.000 & -1.068 & -0.656 & 0.342 \\
\hline No & Prison & $\begin{array}{l}\text { Previous } \\
\text { convictions }\end{array}$ & -1.479 & 0.000 & 1.079 & 0.000 & -0.400 & 0.401 \\
\hline Yes & $\begin{array}{l}\text { Suspended } \\
\text { sentence }\end{array}$ & $\begin{array}{l}\text { Previous } \\
\text { convictions }\end{array}$ & -1.479 & 1.891 & 0.000 & 0.000 & 0.412 & 0.602 \\
\hline Yes & Prison & $\begin{array}{l}\text { No Previous } \\
\text { convictions }\end{array}$ & -1.479 & 1.891 & 1.079 & -1.068 & 0.423 & 0.604 \\
\hline Yes & Prison & $\begin{array}{l}\text { Previous } \\
\text { convictions }\end{array}$ & -1.479 & 1.891 & 1.079 & 0.000 & 1.491 & 0.816 \\
\hline
\end{tabular}

Equation of recidivism for the two extreme cases

a) A probable non recidivist (no previous imprisonment, suspended sentence and no previous convictions)

$Z_{\text {recidivism }}=-1.479+0.000+0.000-1.068=\underline{-2.547}$

$\operatorname{pr}\{$ recidivism $\}=\frac{e^{z}}{1+e^{z}}=\frac{e^{-2.547}}{1+e^{-2.547}}=0.073(7.3 \%$ of risk of recidivism $)$

b) A probable recidivist (previous imprisonment, prison sentence and previous convictions)

$Z_{\text {recidivism }}=-1.479+1.891+1.079+0.000=\underline{1.491}$

$\operatorname{pr}\{$ recidivism $\}=\frac{e^{z}}{1+e^{z}}=\frac{e^{1.491}}{1+e^{1.491}}=0.816$ 
Acknowledgments 


\section{REFERENCES}

Blumstein, A. (2004). Prisons: A policy challenge. In J. Q. Wilson and J. Petersilia (eds.) Crime. Oakland: ICS Press, 451-82.

Cid, J. (2005). The penitentiary system in Spain. Use of imprisonment, prison conditions and rehabilitation. Punishment and Society 7: 147-76.

Cid, J. (coord.), Larrauri, E. (coord.), Escobar, G., Lahoz, J., López i Ferrer, M., Tébar, B., and Varona, D. (2002). Jueces penales y penas en España. (Aplicación de las penas alternativas a la privación de libertad). Valencia: Tirant lo blanch.

Cid, J. and Tébar, B. (forthcoming). Spain. In N. Padfield and D. van Zyl Smit (eds.) Release from prison. European policy and practice. Cullompton: Willan.

Dejong, C. (1997). Survival analysis and specific deterrence: integrating theoretical and empirical models of recidivism. Criminology 35, 561-75.

Farrington, D, Gottfredson, D., Sherman, L. and Welsh, B. (2002). The Mariland Scientific Methods Scale. In L. Sherman, D. Farrington, B. Welsh and D. Layton MacKenzie (eds.) Evidence-based crime prevention. London: Routledge, 13-21.

Gottfredson D.M. (1999). Effects of judges' sentencing decisions on criminal careers. National Institute of Justice. Research in Brief. Washington D. C.: U.S. Department of Justice. 
Harper. G. and Chitty, C. (2005). The impact of corrections on re-offending: a review of 'what works'. Home Office Research Study 291. London: Home Office.

Killias, M., Aebi, M. and Ribeaud, D. (2000). Does community service rehabilitate better than short-term imprisonment? Results of a controlled experiment. The Howard Journal 39, 40-57.

Lloyd, C., Mair, G. and Hough. M. (1994). Explaining reconviction rates: a critical analysis. Home Office Research Study 136. London: Home Office.

Lemert, E. (1972). Human deviance, social problems and social control. New Jersey: Prentice-Hall.

May C. (1999). Explaining reconviction following a community sentence: the role of social factors. Home Office Research Study 192. London: HMSO.

McGuire, J., Priestley, P. (1995). Reviewing 'what works': past, present and future. En J. McGuire (ed.) What works: reducing reoffending. Chichester: Willey.

Petersilia J., Turner S and Peterson, J. (1986). Prison versus probation in California: Implications for crime and offender recidivism. R-3323-NIJ, 1986, The Rand Corporation.

Philpotts, G. and Lancucki S. (1980). Previous convictions, sentence and reconviction. Home Office Research Study 53. London: Home Office. 
Raynor, P. (2007). Risk and need assessment in British probation: the contribution of LSI-R. Psychology, Crime \& Law 13, 125-38.

Sampson R. and Laub J. (1993). Crime in the making. Pathways and turning points through life. Cambridge: Harvard University Press.

Smith L. G. and Akers R. L. (1993). A comparison of recidivism of Florida's community control and prison: A five-year survival analysis. Journal of Research in Crime and Delinquency 30, 267-92.

Spohn, C. (2007). The deterrent effect of imprisonment and offenders stakes in conformity. Criminal Justice Policy Review 18, 31-50.

Spohn, C. and Holleran, D. (2002). The effect of imprisonment on recidivism: a focus on drug offenders. Criminology 40, 329-57.

Walker, N., Farrington, D. and Tucker G. (1981). Reconviction rates of adult males after different sentences. British Journal of Criminology 21, 357-60.

Wilson J. Q. (1983). Thinking about crime. Revised edition. New York: Vintage Books.

Windzio, M. (2006). Is there a deterrent effect of pains of imprisonment? The impact of "social costs" of first incarceration on the hazard rate of recidivism. Punishment \& Society 8, 341-64. 
Table 1 Research on recidivism rates associated with sanctions relevant to test labelling and special deterrence theories

\begin{tabular}{|c|c|c|c|c|c|c|}
\hline Publication & $\begin{array}{l}\text { Sanctions } \\
\text { compared }\end{array}$ & $\begin{array}{l}\text { Scientific } \\
\text { Methods } \\
\text { Scale }(*)\end{array}$ & $\begin{array}{l}\text { Number } \\
\text { of } \\
\text { offenders }\end{array}$ & $\begin{array}{l}\text { Follow- } \\
\text { up } \\
\text { period }\end{array}$ & Results & $\begin{array}{l}\text { Support } \\
\text { for } \\
\text { Labelling } \\
\text { or } \\
\text { Deterrence }\end{array}$ \\
\hline $\begin{array}{l}\text { Walker, } \\
\text { Farrington } \\
\text { and Tucker } \\
(1981)\end{array}$ & $\begin{array}{l}\text { Prison, } \\
\text { suspended } \\
\text { sentence, } \\
\text { probation, } \\
\text { fine and } \\
\text { compensation }\end{array}$ & 2 & 2,069 & 6 years & $\begin{array}{l}\text { First- } \\
\text { offender } \\
\text { prisoners } \\
\text { show lower } \\
\text { rates than } \\
\text { predicted }\end{array}$ & $\begin{array}{l}\text { Supports } \\
\text { special } \\
\text { deterrence }\end{array}$ \\
\hline $\begin{array}{l}\text { Petersilia, } \\
\text { Turner and } \\
\text { Peterson } \\
(1986)\end{array}$ & $\begin{array}{l}\text { Prison and } \\
\text { probation }\end{array}$ & 4 & 1,022 & 2 years & $\begin{array}{l}\text { Prisoners } \\
\text { show } \\
\text { higher rates }\end{array}$ & $\begin{array}{l}\text { Supports } \\
\text { labelling }\end{array}$ \\
\hline $\begin{array}{l}\text { Smith and } \\
\text { Akers } \\
(1993)\end{array}$ & $\begin{array}{l}\text { Prison and } \\
\text { intensive } \\
\text { supervision }\end{array}$ & 3 & 494 & 5 years & $\begin{array}{l}\text { No } \\
\text { significant } \\
\text { differences }\end{array}$ & $\begin{array}{l}\text { No } \\
\text { support } \\
\text { for } \\
\text { labelling } \\
\text { or special } \\
\text { deterrence }\end{array}$ \\
\hline $\begin{array}{l}\text { Lloyd, May } \\
\text { and Hough } \\
\text { (1994) }\end{array}$ & $\begin{array}{l}\text { Prison, } \\
\text { probation, } \\
\text { and } \\
\text { community } \\
\text { service }\end{array}$ & 2 & 17,811 & 2 years & $\begin{array}{l}\text { No } \\
\text { significant } \\
\text { differences }\end{array}$ & $\begin{array}{l}\text { No } \\
\text { support } \\
\text { for } \\
\text { labelling } \\
\text { or special } \\
\text { deterrence }\end{array}$ \\
\hline $\begin{array}{l}\text { Dejong } \\
\text { (1997) }\end{array}$ & $\begin{array}{l}\text { Prison and } \\
\text { non-custodial } \\
\text { sentence }\end{array}$ & 3 & 4,504 & 3 years & $\begin{array}{l}\text { First } \\
\text { offender } \\
\text { prisoners } \\
\text { and } \\
\text { prisoners } \\
\text { with few } \\
\text { social } \\
\text { attachments } \\
\text { show } \\
\text { higher rates }\end{array}$ & $\begin{array}{l}\text { Partial } \\
\text { support } \\
\text { for } \\
\text { labelling }\end{array}$ \\
\hline $\begin{array}{l}\text { Gottfredson } \\
\text { (1999) }\end{array}$ & $\begin{array}{l}\text { Prison, } \\
\text { probation, } \\
\text { fine, } \\
\text { restitution } \\
\text { and prison } \\
\text { plus } \\
\text { probation }\end{array}$ & 3 & 962 & $\begin{array}{l}20 \\
\text { years }\end{array}$ & $\begin{array}{l}\text { No } \\
\text { significant } \\
\text { differences }\end{array}$ & $\begin{array}{l}\text { No } \\
\text { support } \\
\text { for } \\
\text { labelling } \\
\text { or special } \\
\text { deterrence }\end{array}$ \\
\hline Killias, & Prison and & 5 & 123 & 2 years & Prisoners & Support \\
\hline
\end{tabular}




\begin{tabular}{|l|l|l|l|l|l|l|}
\hline $\begin{array}{l}\text { Aebi and } \\
\text { Ribaud } \\
(2000)\end{array}$ & $\begin{array}{l}\text { community } \\
\text { service }\end{array}$ & & & & $\begin{array}{l}\text { show } \\
\text { higher rates }\end{array}$ & $\begin{array}{l}\text { for } \\
\text { labelling }\end{array}$ \\
\hline $\begin{array}{l}\text { Spohn and } \\
\text { Holleran } \\
(2002) \text { and } \\
\text { Spohn } \\
(2007)\end{array}$ & $\begin{array}{l}\text { Prison and } \\
\text { probation }\end{array}$ & 3 & 1,077 & 4 years & $\begin{array}{l}\text { Prisoners } \\
\text { show } \\
\text { higher rates }\end{array}$ & $\begin{array}{l}\text { Support } \\
\text { for } \\
\text { labelling }\end{array}$ \\
\hline
\end{tabular}

(*) Harper and Chitty (2005: 7). 
Table 2 Sample of sentences in Barcelona (1998)

\begin{tabular}{|l|l|l|}
\hline Penalties & $\mathrm{n}$ & $\%$ \\
\hline Prison & 241 & 17 \\
\hline Week-end prison & 33 & 2.4 \\
\hline House arrest & 2 & 0.1 \\
\hline Suspended prison sentence with treatment & 29 & 2.1 \\
\hline Suspended prison sentence & 304 & 21 \\
\hline Fine & 809 & 57 \\
\hline Total & 1,418 & 100 \\
\hline
\end{tabular}


Table 3 Characteristics of the Sample

\begin{tabular}{|l|l|}
\hline VARIABLE & $\% \quad(\mathrm{n}=483)$ \\
\hline Sex & \\
Men & 87.8 \\
Women & 12.2 \\
\hline Age (median 29.5 years ) & \\
\hline Nationality & \\
Spanish & 89.2 \\
Foreigner & 10.8 \\
\hline Financial problems & \\
Yes & 63.5 \\
No & 36.5 \\
\hline Drug-addicted & \\
No & 81.1 \\
Yes & 18.9 \\
\hline Offence & \\
Non-violent property crime & 55.1 \\
Drug dealing & 8.4 \\
Forgery & 6.1 \\
Physical assault & 5 \\
Driving under the influence & 5 \\
Violent property crime & 4.4 \\
Violation of sentence & 4.4 \\
Others & 11.6 \\
\hline Criminal record & 55.6 \\
No previous offences & 44.4 \\
Previous offences & 57.6 \\
\hline Previous prison & 42.4 \\
No & 63 \\
Yes & 37 \\
\hline Sentence & \\
Suspended sentence & \\
Prison & \\
\hline & \\
\hline
\end{tabular}




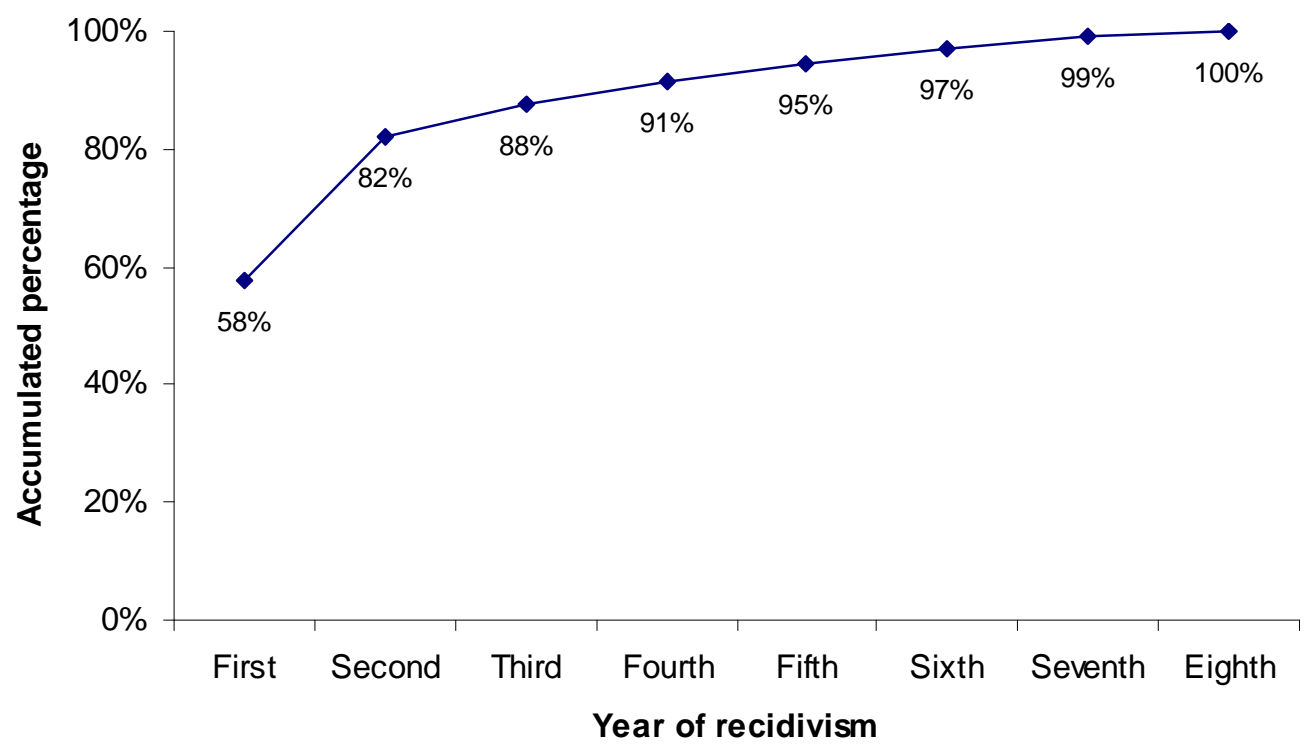

Figure 1 Time of recidivism 


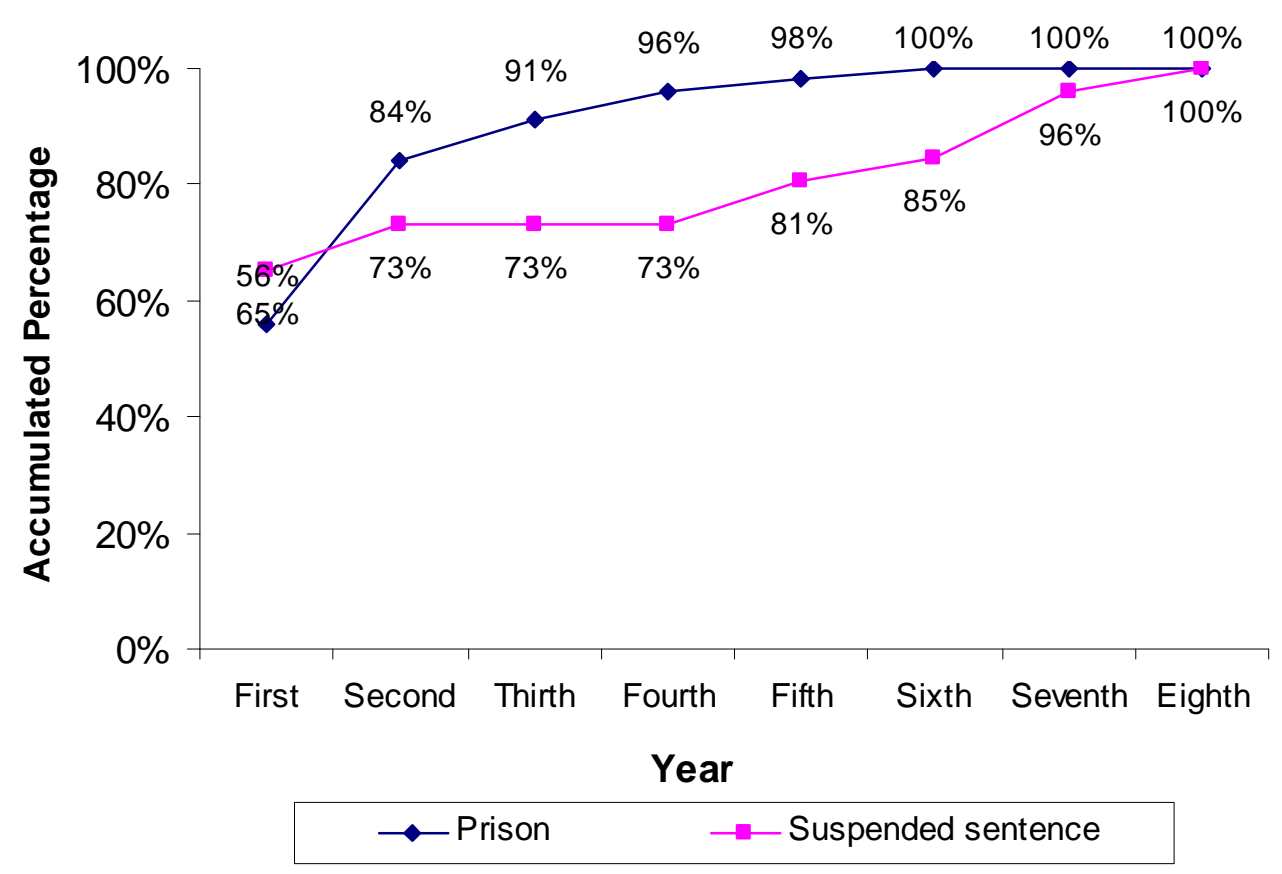

Figure 2 Time of recidivism (prison group and suspended-sentence group) 
Table 4. Variables associated with recidivism

\begin{tabular}{|c|c|c|c|}
\hline & $\mathrm{N}$ & $\%$ RECIDIVIST & $\begin{array}{c}\text { SIGNIFICANCE } \\
\text { (CHI-SQUARE } \\
\text { TEST) }\end{array}$ \\
\hline Age & & & .088 \\
\hline Younger than 29.5 & 254 & 39.8 & \\
\hline Older than 29.5 & 200 & 32 & \\
\hline Sex & & & .134 \\
\hline Men & 424 & 37 & \\
\hline Women & 59 & 27.1 & \\
\hline Nationality & & & .182 \\
\hline Spanish & 425 & 34.8 & \\
\hline Foreigner & 52 & 44.2 & \\
\hline Offence & & & .065 \\
\hline Property & 300 & 40.7 & \\
\hline Others & 157 & 31.8 & \\
\hline Criminal record & & & .000 \\
\hline No previous offences & 255 & 12.5 & \\
\hline Previous offences & 204 & 66.6 & \\
\hline Previous imprisonment & & & .000 \\
\hline No & 278 & 9.7 & \\
\hline Yes & 205 & 71.2 & \\
\hline Financial problems & & & .000 \\
\hline Yes & 294 & 46.9 & \\
\hline No & 169 & 14.8 & \\
\hline Drug addiction & & & .000 \\
\hline No & 361 & 31.6 & \\
\hline Yes & 84 & 54.8 & \\
\hline Penalty & & & .000 \\
\hline Suspended sentence & 304 & 13.8 & \\
\hline Prison & 179 & 73.2 & \\
\hline
\end{tabular}

Note: Number of cases is in some cases lower than the total sample $(n=483)$ due to missing data 
Table 5 Comparison of characteristics for prison group and suspended-sentence groups

\begin{tabular}{|l|c|c|}
\hline & Prison & Suspended sentence \\
\hline Previous imprisonment & $89.2 \%$ & $15.4 \%$ \\
\hline Previous convictions & $93.3 \%$ & $13.3 \%$ \\
\hline Financial problems & $84.7 \%$ & $49 \%$ \\
\hline Drug addiction & $30 \%$ & $13 \%$ \\
\hline
\end{tabular}

Note: All the differences are significant with the chi-square test $\mathrm{p}<.05$. 
Table 6 Effects of sentence on recidivism. Results of logit regression analysis

\begin{tabular}{|l|c|c|c|c|c|c|}
\hline & B & E.T. & Wald & gl & Sig. & Exp(B) \\
\hline $\begin{array}{l}\text { Previous } \\
\text { imprisonment }\end{array}$ & 1.891 & .335 & 31.881 & 1 & .000 & 6.627 \\
\hline $\begin{array}{l}\text { Prison } \\
\text { sentence }\end{array}$ & 1.079 & .443 & 5.928 & 1 & .015 & 2.940 \\
\hline $\begin{array}{l}\text { No previous } \\
\text { offences }\end{array}$ & -1.068 & .462 & 5.346 & 1 & .021 & .344 \\
\hline Constant & -1.479 & .483 & 9.368 & 1 & .002 & .228 \\
\hline
\end{tabular}




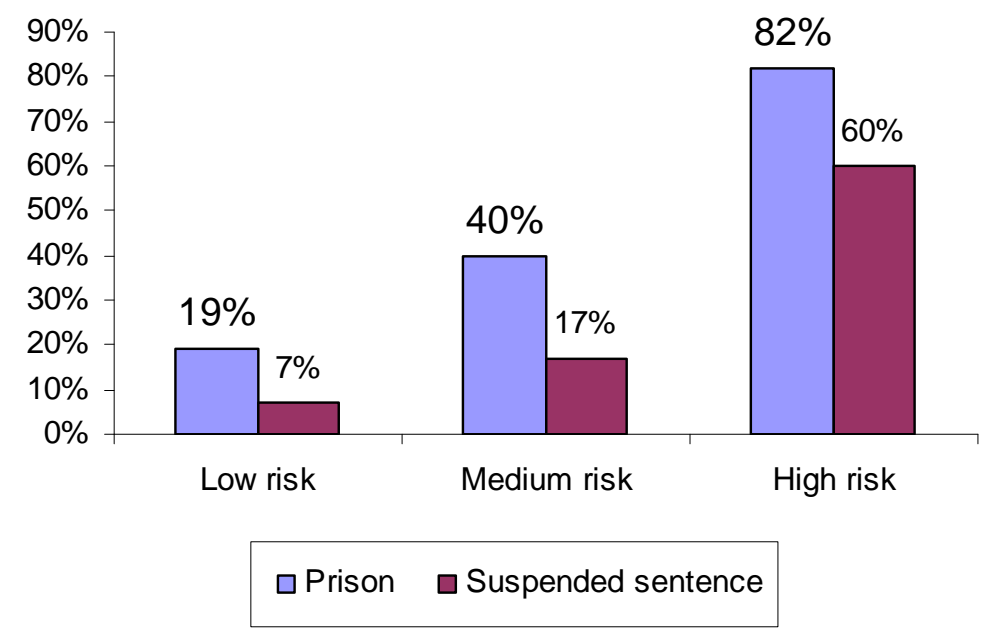

Figure 3. Probability of recidivism according to penalty (prison or suspended sentence) 
${ }^{1}$ I would like to express my gratitude to Eulalia Luque, who carried out the statistical analysis and to Gemma Freixa, who collected the data on recidivism. I have greatly benefited from the comments on an earlier draft of this paper by Marcelo Aebi, Gonzalo Escobar, Alvaro Espinoza, Joel Martí, Elena Larrauri, Marayca López, Peter Raynor, Cristina Rechea, Beatriz Tébar, Daniel Varona and especially the anonymous reviewers from the EJC. The research was funded by the Ministerio de Eduación y Ciencia (Spain) (“La Credibilidad de las Penas Alternativas" SEJ 2005-08095-C02JURI and “Políticas de Reinserción en el Ambito Penal" DER 2008-05041), by the Catalan Government (“Grupo de Investigación en Criminología Aplicada a la Penología” AGAUR, 2005, SGR 00824) and by the Catalan Centre d'Estudis Juridics i Formació Especialitzada (Research funds, 2006).

${ }^{2}$ As noted by the anonymous reviewer, imprisonment may be relevant to recidivism, although not exactly as a consequence of labelling but rather as an effect of possible breakdowns in social networks (accommodation, employment or relationships) due to temporarily having been out of society. My research does not make it possible to distinguish between these two possible explanations for the correlation between imprisonment and recidivism.

${ }^{3}$ Apart from specific deterrence and labelling theories, a third theory-rehabilitation theory-should also be evaluated when the penalty carries a specific intervention addressing the criminogenic needs of the offender (McGuire-Priestley 1995). However, in this research, rehabilitation theory will not be examined as the two penalties compared (prison and suspended sentence) did not generally place a rehabilitative intervention on the offender.

${ }^{4}$ See May (1999) on the importance of social factors in the prediction of recidivism.

${ }^{5}$ Notwithstanding this, the use of imprisonment as a measure of recidivism would be unacceptable if judges punished offenders having a previous unsuspended prison sentence more severely than offenders with a previous suspended prison sentence, as in 
this case rates of recidivism would be biased in favour of the suspended sentence.

Although this could be a significant objection to the method used in this research, it is important to consider that, in accordance with the Spanish criminal code, revocation of the suspended sentence is mandatory for judges if any new offence is committed during the suspension term. Nevertheless, there is always the possibility that, in certain cases in which the new offence is committed once the term of suspension is over, judges may use lack of previous imprisonment as a factor in the offender's favour. Regrettably, no Spanish research has yet been carried out on this question.

${ }^{6}$ According to the research by Cid and Larrauri et al. (2002) from the date of the offence to the date of the implementation of the sentence there is an average of 3.2 years.

${ }^{7}$ Given that the judicial files used to obtain the primary data do not always contain specific information on the offender's financial situation, in this research I assumed that the offender did not have financial problems when at least one of the following criteria had been met before the judge sentenced the offender: a) he/she was assisted by a paid lawyer (rather than a state lawyer); b) if the offender was fined he/she paid or c) if the sentence included compensation for the victim, the compensation was paid. If any of the three criteria was not met, then the offender is deemed to have financial problems. ${ }^{8}$ According to research by Cid, Larrauri et al. (2002) the factors taken into account by judges when sentencing an offender to prison rather than to a non-custodial sanction were: nationality (foreigner), previous convictions, drug-addiction, financial problems, plea of not guilty and opposition by the prosecutor to the non-custodial sanction. With the exception of the last two, all of these factors have been considered in this research. The guilty plea has been disregarded because in the previous research this is not usually seen as a factor significantly linked to recidivism. The public prosecutor's opposition to a non-custodial sentence has been excluded since such opposition is always based on the offender's criminal record, and this factor is already considered by the research. 